\title{
Molecular characterization of cellulolytic (endo- and exoglucanase) bacteria from the largest mangrove forest (Sundarbans), Bangladesh
}

Satyajit Biswas ${ }^{1 \dagger}$, Md. Al Saber ${ }^{1 \dagger}$, Ismoth Ara Tripty ${ }^{1}$, Md. Adnan Karim²,2, Md. Aminul Islam ${ }^{1}$, Md. Shazid Hasan³, A. S. M. Rubayet UI Alam ${ }^{3}$, Md. lqbal Kabir Jahid ${ }^{3}$ and Md. Nazmul Hasan ${ }^{1 *}$ (D)

\begin{abstract}
Purpose: Cellulase, due to its massive applicability, has been used in various industrial processes such as biofuels (bioethanol, triphasic biomethanation), agricultural and plant waste management, chiral separation, and ligand binding studies. The finding of a novel cellulase-producing bacterium will benefit the industries, which rely on yeast to produce cellulase in fermentation technology, because bacteria can easily be manipulated and fermented cost-effectively.

Methods: Cellulase enzyme-secreting bacteria were isolated from different regions of the world's largest mangrove forests, Sundarbans in Bangladesh. Biochemical, morphological, and 16S rRNA identification protocol was followed to precisely characterize the bacterial strains.

Result: We have determined that the strain T2-D2 (Bacillus sp.), E1-PT (Pseudomonas sp.), and D1-PT (Pseudomonas sp.) showed maximum endoglycolytic and strain C1-BT (Bacillus sp.), E1-BT (Bacillus sp.), and T-4 (E) showed relatively higher exoglycolytic activity during the test. So, it can be easily cultured at a normal temperature (97.7-99.5 $\left.{ }^{\circ} \mathrm{F}\right)$. On the one hand, T2D2 (Bacillus sp.) and E1-PT (Pseudomonas sp.) have shown the highest growth rate at pH 7 as it was neither acidic nor basic.

Conclusion: It was concluded that the strain T2-D2 (Bacillus sp.) and E1-PT (Pseudomonas sp.) would be our target cellulolytic strains wherein the experimental isolates belonged to the Enterobacteriaceae, Psuedomonacea, Bacillacea, and Morganellacea family.
\end{abstract}

Keywords: Cellulolytic bacteria, Endoglucanase, Exoglucanase, Mangrove forest, Bangladesh

\section{Introduction}

Mangrove forests are enriched with groups of trees and shrubs and have substantial ecological importance at the tropical side and economic significance on universal scales. One of the largest mangrove forests in the world is Sundarbans located in the south-west between the river Baleswar

\footnotetext{
* Correspondence: mnhasan1978@gmail.com

${ }^{\dagger}$ Satyajit Biswas and Md. Al Saber contributed equally to this work. 'Laboratory of Pharmaceutical Biotechnology, Department of Genetic Engineering and Biotechnology, Faculty of Biological Science and Technology, Jashore University of Science and Technology, Jashore 7408, Bangladesh

Full list of author information is available at the end of the article
}

in the East and the Harinbanga in the West, adjoining to the Bay of Bengal (Biswas et al. 2007). Having a rich biological diversity among the plants, animals, and microbes, Sundarbans is surrounded by terrestrial and marine ecosystems. To maintain the ecological balance and the biological diversity among the living material such as plant derived parts like litter, wood, leaf, stems, and so on have to be decomposed by some metabolic process. These metabolic processes of decomposition are often controlled by diverse groups of naturally growing microbes in the mangrove forest. The habitat and ecological diversity of these microbes

(c) The Author(s). 2020 Open Access This article is licensed under a Creative Commons Attribution 4.0 International License, which permits use, sharing, adaptation, distribution and reproduction in any medium or format, as long as you give appropriate credit to the original author(s) and the source, provide a link to the Creative Commons licence, and indicate if changes were made. The images or other third party material in this article are included in the article's Creative Commons licence, unless indicated otherwise in a credit line to the material. If material is not included in the article's Creative Commons licence and your intended use is not permitted by statutory regulation or exceeds the permitted use, you will need to obtain permission directly from the copyright holder. To view a copy of this licence, visit http://creativecommons.org/licenses/by/4.0/. 
may depend on their features, characteristics, and synergistic metabolic function.

Plant materials are composed of cellulose, which is the main component of plant cell walls. In general, cellulose is an organic compound having long-chained sugar (beta-Dglucose) linked to their organic structure; therefore, they are often called a polysaccharide. These sugar chain complex structures give the plant cell wall a remarkable heavy strength. Therefore, microbes have difficulties in breaking down these sugar bonds among the plant cell walls. Nevertheless, several microbes degrade cellulose material and sustain ecological balance among the forest. Among the cellulose-degrading microbes, few microbes have synergistic features to produce byproducts during the degradation of cellulolytic material. This characteristic means they may have capacity to convert cellulose or sugar or glucose compounds into gases, ethanol, acid, and several types of toxic compounds. Therefore, based on their synergistic features and economic importance, few natural microbes were chosen industrially for human welfare. In contrast, few microbes were modified using available modern technology, which was also for beneficial purposes.

Due to the rich biological diversity, decomposition of living material is required to sustain continuous ecological diversity. Diverse groups of microbes having bifunctional or particular types of decomposing ability favor living material to decompose soon. However, some materials like litter, woods, leaves, and stems take more time to decompose as it is difficult for some microbes to decompose. These materials are composed of cellulose, categorized at different types based on their structure (Thatoi et al. 2013). According to their types, microbes produce enzymes that penetrate the cellulolytic parts and degrade the weak to heavy structured portion. This portion comprises of heterogeneous polysaccharide chains, such as hemicelluloses, pectins that are embedded in lignin (Tomme et al. 1995). Aerobic, anaerobic bacteria, and fungi display cellulase enzymatic activity, and their biochemical analysis has been done comprehensively during the past few decades. Till now, three major types of enzymatic activity have been observed: (a) endoglucanases or 1, 4-beta-D-glucan-4-glucanohydrolases, (b) exoglucanases, including 1, 4-beta-D-glucan glucanohydrolases (also known as cellodextrinases: synonyms or derivatives of cellulose) and 1, 4-beta-D-glucan cellobiohyrolases, and (c) beta-glucosidases or glucohyrolases (Barkalow et al. 1989). Bacteria, fungi, protozoa, and algae play a significant role in degrading cellulose, and among them, 91\% cellulose was degraded by bacteria and fungi (Holguin and Bashan 1996). Among them, fungi have been used traditionally in many fermentation industries as it is easy to find compared to the other cellulose-degrading crude materials. But, due to the complexity in culturing and scarcity of promising strains, fungi-based alcohol production may not be economically beneficial. whereas for bacteria having similar alcohol converting ability from the same cellulose products, it could be an alternative crude material for the cellulase enzyme-dependent industries as it is easily accessible to culture, with less toxicity compared to the fungi. However, the promising strain with a bifunctional activity (exo- and endoglucanase) is still missing; therefore, findings of novel strain promising for fermentation industries is in search. In that case, mangrove forests could be the ideal place to find out the novel bacterial strain, having required bifunctional features.

A Bacillus strain was isolated from Thailand's mangrove swamps forest with relatively higher endoglucanase activity than the previously reported bacterial strains; however, its bifunctional cellulase producing ability was lower. Another Bacillus strain was isolated from Brazil's mangrove forest with bifunctional (exo- and endoglucanase) ability for enzyme production. However, this bacterial strain was only able to display particular bifunctional feature in the presence of saline, which might suggest that their investigated Bacillus strain might have unique feature compared to other findings. However, industrially used bacterial strains are only focused on endoglucanase or CMCase activity because industrially used raw cellulose materials are less amorphous and have less robust complex binding modules (CBMs). Kinetics of industrially used bacterial bifunctional activity has been investigated, and it displayed highly CMCase activity similar to the previously described bacterial strains. However, those bacterial strains were anaerobic and being used in industries because of less toxicity and having suitable maintaining ability (Manfredi et al. 2018; Singh et al. 2019). Several studies have recently been focusing on bacterial exoglucanase (avicellase) and endoglucanase (CMCase) activity because not only fermentation industries but also cellulase-dependent industries are moving to use strong molecular weight cellulose. Finding bifunctional bacterial strain is therefore essential and required for heavy cellulose-using industries.

The exoglucanases act both in the reducing and nonreducing ends of cellulose polysaccharide chains, thus generating either glucose (glucanohydrolases) or cellobiose (cellobiohydrolase)-leading derivatives or products. The exoglucanases often act as microcrystalline cellulose; thus, the enzyme shows the microcrystalline structure (Teeri 1997). Studies suggested that cellulolytic bacteria often generate soluble extracellular cellulases termed as cellulosomes, a multi-enzyme extracellular complex which acts as a degrader of lignocellulosic biomass (Bayer et al. 1998; Lynd et al. 2002; Artzi et al. 2014). The part of the insoluble portion of cellulose that is often referred to as cellulosomes (microcrystalline) has limited ATP available for cellulose synthesis. Anaerobic bacteria can penetrate this portion of cellulose.

On the other hand, aerobic bacteria easily penetrate the "free" cellulose with or without cellulose-binding 
modules (CBMs). They may therefore pull over the efficient hydrolysis of cellulose under non-complexed conditions. The enzymes liberated from aerobic bacteria do not form stable high molecular weight complexes, and therefore they form a non-complexed system (Henrissat et al. 1998; Eriksson et al. 2012). Multiple enzymes or CBMs are highly organized with dockerin/cohesion domains and scaffold proteins at the complex cellulose systems.

The main aim of this study was to characterize aerobic or facultative anaerobic bacteria from the Sundarban mangrove forest as it is having large microbial-like bacterial diversity. Besides, we tried to observe their bifunctional (endo- and exoglucanase) features and found that the mangrove forest Sundarban, which is enriched with large microbial biodiversity, has been ignored as well as yet not studied very well. During this study, we collected several bacterial stains from the Sundarban and found some bacterial strains that can display efficient bifunctional characteristics, and they were nor acidic or basic.

\section{Method and Materials Collection, isolation, and primary screening of cellulolytic bacteria}

Initially, soil samples were collected from mangrove forests of Bagerhat district, Bangladesh. Soil samples were collected from the Sundarban (between $21^{\circ} 48^{\prime} 43.8^{\prime \prime} \mathrm{N}$ and $89^{\circ} 33^{\prime} 49.1^{\prime \prime} \mathrm{N}$ latitude and $21.812174 \mathrm{E}$ and 89.563636E longitude), Bangladesh. It is observed that the experimental samples contain an average organic carbon density of $1.19 \mathrm{~kg} / \mathrm{m}^{2}$ and the $\mathrm{pH}$ was 5.9 . Carbon density was measured by using the standard method described by Jackson (1956). The texture of the soil was silts loam.

Mangrove forest was chosen because of its inherent biodiversity and also to explore its industrial importance. The samples were collected in a sterile polybag and kept it at $4{ }^{\circ} \mathrm{C}$ until use. Water was sprayed over the soil samples for maximum bacterial growth. Bacterial colonies were then transferred into the test tube containing nutrient broth (HIMEDIA: peptone $10 \mathrm{~g} / \mathrm{l}^{-1}$, beef extract $10 \mathrm{~g} / \mathrm{l}^{-1}$, sodium chloride $5 \mathrm{~g} / \mathrm{l}^{-1}, \mathrm{pH} 7.3 \pm 1$ ) as an enrichment media for bacterial growth. Whatman No.1 filter paper (materialcircles cellulose filter; diameter-110 $\mathrm{mm}$; thickness$180 \mu \mathrm{m}$; pore size $-11 \mu \mathrm{m}$; weight $-87 \mathrm{~g} / \mathrm{m}^{2}$ ) was used as a growth enhancer (crushed and then immersed along with soil sample inside the media), and then the broth along with bacteria was kept for $72 \mathrm{~h}$ in a shaking incubator at $37^{\circ} \mathrm{C}$ for $180 \mathrm{rpm}$. Ten-fold serial dilution on the nutrient broth was done using autoclaved peptone water after incubation after incubation. The serially diluted broth then transferred to the carboxymethylcellulose (CMC) agar plates using a micro-pipet and spread it over the CMC agar plates using a glass rod and then incubated for $48 \mathrm{~h}$. The carboxymethylcellulose (CMC) agar medium used for the isolation of cellulolytic bacteria contained $1 \mathrm{~g} / \mathrm{l}$ yeast extract, $3 \mathrm{~g} / \mathrm{l}$ agar, $26 \mathrm{~g} / \mathrm{l}$ carboxymethyl cellulose, $1 \mathrm{~g} / \mathrm{l}$ ammonium dihydrogen phosphate, $0.2 \mathrm{~g} / \mathrm{l}$ potassium chloride, and $1 \mathrm{~g} / \mathrm{l}$ magnesium sulfate heptahydrate. After the incubation period, bacterial cultures transferred to the new fresh culture media to identify cellulolytic bacteria. Then we flooded the mother culture with Congo red solution at room temperature for 10 min and then washed with $\mathrm{NaCl}$. The clear halo zone region indicated that CMC agar was hydrolyzed, and bacterial colonies were visualized.

\section{Isolation and estimation of enzymatic activity}

Cellulase enzyme was extracted from the bacterial culture by the centrifuge machine. LB broth containing bacterial cultures was incubated for $24 \mathrm{~h}$ at $37^{\circ} \mathrm{C}$ and then centrifuged at $14,000 \mathrm{rpm}$ for $4 \mathrm{~min}$ at $4{ }^{\circ} \mathrm{C}$. The supernatant was collected using $0.1 \mathrm{ml}$ micro-pipet and stored at a $-20^{\circ} \mathrm{C}$ freezer. Thereafter, endoglucananse (CMC/ cellulose) and exoglucanase (microcrystalline/avicellase) activities have been analyzed using the previously collected bacterium's supernatants followed by a modified method of Liang et al. (2014).

One (01) $\mathrm{ml}$ of supernatant enzyme was transferred to the 4-in. test tube and added $1 \mathrm{ml}$ of $\mathrm{CMC} /$ microcrystalline solubilized phosphate buffer solution with $\mathrm{pH} 4.8$ (1\%). Cellulose or microcrystalline cellulose $(1 \mathrm{~g})$ was added to the mixture and then incubated at $37^{\circ} \mathrm{C}$ for 30 min with $120 \mathrm{rpm}$. After that, $1 \mathrm{ml}$ of DNS (dintrosalicyclic acid) was added to the incubated test tube, and the mixture solution was then boiled for $5 \mathrm{~min}$ at $100^{\circ} \mathrm{C}$ in the water bath. Free sugars were determined by measuring absorbance at $540 \mathrm{~nm}$ (Spectrometer model: T60 UVvisible spectrometer; UV-1800 UV spectrometer). One unit of enzyme activity defined as micromole substrate consumed or product formed per minute. Cellulase production was estimated using a glucose calibration curve (Lamed et al. 1987; Shaikh et al. 2013; Khan et al. 2017).

\section{Salinity test}

Five percent $(5 \%) \mathrm{NaCl}$ added to the carboxymethylcellulose (CMC) agar plates. The bacterial colonies displayed a silver zone after adding $\mathrm{NaCl}$ to the agar media. This test was conducted separately to observe how condition isolated bacterial samples displayed the highest growth (CMCase media with and without salt; $\mathrm{NaCl}$ ), as they were isolated from mangrove forests where the salt concentration in soil is much higher than in general.

\section{Identification of the cellulase-producing bacteria}

At first, isolates were identified through morphological and biochemical characteristics. The biochemical tests performed were as follows: triple sugar iron agar test, IMViC test (indole test, methyl red test, Voges-Proskauer test, and citrate utilization test), catalase test, oxidase test, and Congo red test. The protocols prepared during this 
experiment based on published standard method (McFadden 1980; Holt and Krieg 1984; MacFaddin 1985; Tittler and Sandholzer 1996; Boon et al. 2007; Sigma-Aldrich Co. n.d.). For morphological identification, Gram's staining test was done according to the manual of veterinary laboratory techniques in Kenya in 1981 (Anonymous 1981).

\section{Species segregation}

It was finally concluded that isolated 17 samples were cellulose-degrading bacteria. They can grow on selective media carboxymethylcellulose (CMC) agar, and they displayed a halo zone region during the Congo red test.

To segregate the species, we used different selective media like King's A media that contained the following: $16 \mathrm{~g} / \mathrm{l}$ peptic digest of animal tissue, $10 \mathrm{~g} / \mathrm{l}$ casein enzymic hydrolysate, $10 \mathrm{~g} / \mathrm{l}$ potassium sulfate, $1.4 \mathrm{~g} / \mathrm{l}$ magnesium chloride, and $11 \mathrm{~g} / \mathrm{l}$ agar, $\mathrm{pH} 7.1 \pm 0.2$ at $25^{\circ} \mathrm{C}$ used for the segregation of Pseudomonas sp. For Bacillus sp., specific selective media was used, and they contained the following: $2 \mathrm{~g} / \mathrm{l}$ peptone, $2 \mathrm{~g} / \mathrm{l}$ yeast extract, $5 \mathrm{~g} / \mathrm{l}$ dextrose, $15 \mathrm{~g} / \mathrm{l}$ agar, pH $6.9 \pm 0.2$. Before that, isolated soil samples were transferred to the test tube (10 inches) with one or two drops of water. Then the tube was incubated at $80^{\circ} \mathrm{C}$ water bath for a minimum of $10 \mathrm{~min}$, and then transferred to selective media and incubated for $48 \mathrm{~h}$. Enterobacteriaceae sp. can be obtained by using Macconky agar. On Macconky agar, Klebsiella sp. displayed big colonies with a sticky pink color, Salmonella sp. showed mild growth with a whitishpink color, E. coli displayed an accurate pink color, and Proteus sp. showed a gray color with mild growth. The appearances of color and characteristics of bacterial species were observed within $18-24 \mathrm{~h}$ because appearances would be quickly changed if investigation was delayed.

\section{Biochemical test Catalase test}

A loop or sterile stick was utilized to transfer few bacterial colonies to the surface of a sterilized, dry glass slide, and then a drop of $3 \%$ hydrogen peroxide $\left(\mathrm{H}_{2} \mathrm{O}_{2}\right)$ was placed onto the medium. The production of oxygen was observed by the formation of bubbles.

\section{Oxidase test}

$\mathrm{OX}^{+}$typically means the bacterium contains cytochrome $c$ oxidase and can use oxygen for energy production by converting $\mathrm{O}_{2}$ to $\mathrm{H}_{2} \mathrm{O}_{2}$ or $\mathrm{H}_{2} \mathrm{O}$ with an electron transfer chain. $\mathrm{OX}^{-}$typically means the bacterium having an incapability to oxidize cytochrome $\mathrm{c}$ and, therefore, either cannot use oxygen for energy production within the electron transfer chain or employs a different cytochrome for transferring an electron to oxygen. An oxidase disc containing the reagent was used, then the colony was picked and rubbed on the disc. After waiting for a few seconds, the color was observed.

\section{Indole test}

A filter paper was saturated with the $1 \%$ pdimethylaminocinnamaldehyde reagent, and then a loop was used to remove a bacterial colony from the agar surface to the filter paper. After 2 min, the color was developed on the filter paper.

\section{Citrate agar test}

Isolates were inoculated in the Simmon citrate agar by using the loop or cotton plug, and the media containing tube was kept into the $37^{\circ} \mathrm{C}$ shaker incubator $(140 \mathrm{rpm})$ overnight.

\section{Motility test}

A needle was used to pick a colony from the $(20 \mathrm{~h}) \mathrm{cul}$ ture growing on specific (pancreatic digest of gelatin $10.0 \mathrm{~g} / \mathrm{l}$, sodium chloride $5.0 \mathrm{~g} / \mathrm{l}$, beef extract $3.0 \mathrm{~g} / \mathrm{l}$, agar $4.0 \mathrm{~g} / \mathrm{l}, \mathrm{pH} 7.3 \pm .03$ at $25^{\circ} \mathrm{C}$ ) agar medium and then stabbed down to the center of the tube. After that, incubation was done at $35-37^{\circ} \mathrm{C}$, and routine observation was carried for 5 days (Swenson et al. 2011).

\section{Triple sugar iron test}

An isolated colony was transferred to the TSI agar medium (pancreatic digest of casein $15 \mathrm{~g} / \mathrm{l}$, lactose $10.0 \mathrm{~g} /$ $\mathrm{l}$, sucrose $10.0 \mathrm{~g} / \mathrm{l}$, sodium chloride $5.0 \mathrm{~g} / \mathrm{l}$, peptic digest of animal tissue $5.0 \mathrm{~g} / \mathrm{l}$, yeast extract $3.0 \mathrm{~g} / \mathrm{l}$, beef extract 3.0 $\mathrm{g} / \mathrm{l}$, dextrose $1.0 \mathrm{~g} / \mathrm{l}$, ferric ammonium citrate $0.5 \mathrm{~g} / \mathrm{l}$, sodium thiosulfate $0.3 \mathrm{~g} / \mathrm{l}$, phenol red $0.024 \mathrm{~g} / \mathrm{l}$, agar $12.0 \mathrm{~g} / \mathrm{l}$, $\mathrm{pH} 7.3 \pm .03$ at $25^{\circ} \mathrm{C}$ ) to the bottom of the tube, and then streaking was done on the agar slant. After that, incubation was conducted on the same tubes at $36^{\circ} \mathrm{C}$ in an ambient air condition for $20 \mathrm{~h}$ (Swenson et al. 2011).

\section{MR-VP test}

Common media was prepared for the MR-VP reaction containing peptone $7 \mathrm{~g} / \mathrm{l}$, glucose $5 \mathrm{~g} / \mathrm{l}$, phosphate buffer 5 $\mathrm{g} / \mathrm{l}, \mathrm{pH} 6.9 \pm 0.2$, and two types of indicators used during separating the species. Actually, particular indicators used in MR-VP test categorized the reaction: MR (methyl red) reaction and VP (Voges-Proskauer test) reaction.

For MR-reaction, methyl red added on the media containing isolated samples after $24-36 \mathrm{~h}$ incubation. For VP reaction, Barrit's B reagent was added after $18-24 \mathrm{~h}$ incubation period. The details of the species separation and identification have been described on Tille (2016).

\section{Identification by $16 \mathrm{~S}$ rRNA gene}

The molecular identification of strains was conducted by $16 \mathrm{~S}$ rRNA amplification, sequencing, and analysis, using the universal primers, $27 \mathrm{~F}$ and $1492 \mathrm{R}$, and we extracted by a boiling method (Millar et al. 2000), with slight modifications. PCR reactions were conducted using a total volume of $20 \mu \mathrm{l}$, containing $10 \mu \mathrm{l}$ of Promega Taq i $2 \times$ 
Green Master Mix, $0.5 \mu \mathrm{l}$ each of forward and reverse primers, $6 \mu \mathrm{l}$ of DNase-free water, and $2 \mu \mathrm{l}$ of DNA template. The amplification protocol was composed by initial denaturation at $94^{\circ} \mathrm{C}$ for 5 min which preceded 1 min denaturation at $94{ }^{\circ} \mathrm{C}$ for 35 cycles, annealing at $55^{\circ} \mathrm{C}$ for $30 \mathrm{~s}, 45$-s extension at $72{ }^{\circ} \mathrm{C}$, and a final extension at $72{ }^{\circ} \mathrm{C}$ for $5 \mathrm{~min}$.

After amplification, $10 \mu \mathrm{l}$ of PCR products was analyzed for electrophoresis in a $1.2 \%$ agarose gel in $0.5 \times$ TrisBorate-EDTA (TBE) buffer (BioRad) stained with ethidium bromide $(2 \mu \mathrm{g} / \mathrm{ml})$. Also, a 1-kb Ladder (PROMEGA, USA) was used as a marker, and the visualization of agarose gels was conducted by transillumination under UV light using Image Master (Pharmacia Biotech, UK). The PCR product with $1.5 \mathrm{~kb}$ as the expected size was excised and purified using MEGAquick-spin (TM) PCR \& Agarose Gel DNA Extraction System (NtRON Biotechnology, Korea) and sequenced.

\section{Sequence data generation}

Afterward, we purified PCR amplicons using the Wizard ${ }^{\circ}$ SV Gel and PCR Clean-Up System (Promega, USA) and sequenced using Z-BigDye ${ }^{\oplus}$ Terminator v3.1 cycle sequencing kit (Applied Biosystems ${ }^{\circ}$, USA). We generated raw data in the ABI Genetic Analyzer (Applied Biosystems ${ }^{\circ}$, USA) before the data assembly implementing with SeqMan version 7.0 (DNASTAR, Inc., Madison, WI, USA). The sequence data were further compared with the NCBI GenBank database using BLAST to identify the LAB strains, followed by the submission of sequence. We implied the maximum likelihood method for inferring the evolutionary history of the bacteria using 16S rRNA data conducted in MEGA7 based on the Tamura-Nei model.

\section{Results}

Isolation of cellulolytic bacteria from mangrove forest In this work, we have collected and investigated the cultivable CMC-degrading bacterial community from the selected parts of the Sundarban. After screening mangrove soil, $17 \mathrm{CMC}$-degrading isolates were obtained from these samples, which were able to grow on the CMC agar plates and used carboxymethyl cellulose as their sole carbon sources as well as all of them were able to hydrolyze CMC agar plates and displayed halo zone region on the all CMC agar plates. The same results were reported for Acinetobacter anitratus and Branhamella sp. fully grown in a basic salt medium with glucose and CMC as sole carbon supply on an individual basis. Ekperigin (2007) quantitatively identified the cellulase-degrading enzyme of $A$. anitratus and Branhamella sp. Gupta et al. (2012) isolated eight bacterial isolates, and it was found to be positive on screening media (cellulose Congo red agar), producing a clear zone.
Characterization of bacterial isolates by biochemical and morphological analysis

\section{Morphological test}

The Gram staining test determined the morphological features of the isolates. Fourteen (14) isolates were gramnegative except three isolates, which were rod-shaped. Barman et al. (2011) isolated native populations of bacteria from different habitats like soil, drain, and garbage for bioconversion of cellulose, and the diversity was characterized, where out of five, four isolates were Gram-positive and one was Gram-negative (Barman et al. 2011).

\section{Biochemical test}

Catalase test All the isolated samples showed to be catalase-positive during the test, which means all can secrete gas or oxygen.

$$
2 \mathrm{H}_{2} \mathrm{O}_{2}=2 \mathrm{H}_{2} \mathrm{O}+\mathrm{O}_{2}
$$

C1-BT and E1-BT isolates displayed the highest catalase activity during this test.

Oxidase test An oxidase disc containing the reagent was used, then the colony was picked and rubbed on the disc. After waiting for $10 \mathrm{~s}$, the color changed was observed. Seven isolates were catalase-positive out of 17 isolates.

Indole test From the 17 isolated samples, only three were indole-positive, and others displayed negative results. This test is used to identify whether the selected isolates can convert tryptophan to indole. It is one of the tests of the IMViC series, which is done for evidence of an enteric bacterium. This test was done to observe whether the isolated organisms belong to the coliform group.

Citrate agar test Among the 17 isolates, only four isolates showed to be negative during the test. Isolates were inoculated in the Simmon citrate agar, where bromothymol blue was used as a $\mathrm{pH}$ indicator. $\mathrm{pH}$ defines whether they are alkaline or not. The color of the media was changed green to blue for $\mathrm{K}, \mathrm{S} 1, \mathrm{~S} 2$, and P isolates after the inoculation period. Though E. coli is Enterobacteriaceae, they cannot show these characteristics because they lack the Citrase enzyme, which prohibits them from breaking down citrate.

Motility test Among the 17 isolates, only one showed a negative result. A motility test is done to identify whether the selected isolates possess flagella by observing their ability to swim on the semi-solid medium or not.

Triple sugar iron agar test Nine (09) out of 17 isolates displayed positivity during the TSI test and showed red 
color on both the slant and butt of the test tube, which means they can produce alkaline or acid. These acids are converted to alcohol later, whereas others remained negative.

MR-VP test Only one isolate showed to be MR-positive during the test, and seven isolates were VP-positive. When E1, E2, P, and S1 isolates were mixed with glucose during the MR test, it was fermented into acid. In this process, it gave $4 \mathrm{~mol}$ of acidic products (lactic acid and acetic acid), $1 \mathrm{~mol}$ of neutral fermentation product (ethanol, $1 \mathrm{~mol} \mathrm{CO}, 1 \mathrm{~mol} \mathrm{H}_{2}$ ) in per mol of glucose fermentation. The consequence was decreased $\mathrm{pH}(<4.4)$ in medium for the positive samples and relatively higher $\mathrm{pH}(>5.1)$ for the negative samples.

Five isolates showed to be VP-positive during the test. Basically, in the laboratory, this test was done to detect acetone, which was called (R)-acetone. Samples E1-PT, A2-PT, C1-PT, D1-PT, and D2-PT remained negative or null both for the MR-VP test, which means they do not produce acetone or ferment acid. The biochemical test results of isolated samples were shown in Table 1.

Through the microscopic observation, it was observed that all isolates were Gram-negative except S1, S2, and B1-BT. A total of 6 bacterial strains had been identified based on cultural and microscopic characteristics and based on biochemical analysis. Isolated strains were finally identified by comparing with "Bergey's Manual of Determinative Bacteriology" by Buchanan and Gibbons (Plate
1) (Buchanan and Gibbons 1974). They are Pseudomonas sp. (E1-PT, A2-PT, and S1-PT), Bacillus sp. (B1-BT), Escherichia sp. (C1-BT, A1-BT, and E1-BT), Klebsiella sp. (D1-ST), Salmonella sp. (K and D2-BT), and Proteus sp. (E1, E2, S1, and S2).

\section{Estimation of exoglucanase and endoglucanase activity}

Out of 12 isolates, all of the samples had the exoglucanase activity, and they showed low, mild, and higher states during the test. We have found out three novel isolates that showed the highest exoglucanase activity during the test, and they are D1-PT, E1-PT, and T2-D2 (Fig. 1). These top 3 samples were our novel isolates, which had the highest exoglucanase activity. Similar to the exoglucanase test, the endoglucanase (avicellase) activity was done and tested. We had investigated the 17 samples for endoglucanase activity and brought out three novel samples. The C1-BT, E1-BT, and B1-BT were our novel samples as they showed the highest endoglucanase activity during the test (Fig. 2).

\section{Effect of $\mathrm{pH}$ test}

After analyzing the data of the test results, we found from the 17 isolates that $\mathrm{pH} 7$ was novel for optimum growth. It was neither acidic nor basic. At $\mathrm{pH} 7$, all of the isolates showed a maximum growth rate compared to that at $\mathrm{pH}$ 9. Though few samples like D2-PT and C1-BT displayed maximum growth at $\mathrm{pH} 9$ (Fig. 3), their growth was similar for $\mathrm{pH} 7$ (Fig. 4).

Table 1 Results of the biochemical test of isolated samples

\begin{tabular}{|c|c|c|c|c|c|c|c|c|c|}
\hline Samples & Catalase & Oxidase & Motility & Citrate & TSI & Indole & MR & VP & Congo red \\
\hline E1-PT & + & + & + & + & - & - & - & - & + \\
\hline A2-PT & + & + & + & + & - & - & - & - & + \\
\hline C1-PT & + & + & + & + & - & - & - & - & + \\
\hline D1-PT & + & + & + & + & - & - & - & - & + \\
\hline D2-PT & + & + & + & + & - & - & - & - & + \\
\hline B1-BT & + & + & + & + & - & - & - & + & + \\
\hline D2-BT & + & - & + & + & - & - & - & + & + \\
\hline C1-BT & + & - & + & - & + & + & - & - & + \\
\hline T2-D2 & + & + & + & + & - & - & - & + & + \\
\hline$A 1-B T$ & + & - & + & - & + & + & - & - & + \\
\hline E1-BT & + & - & + & - & + & + & - & - & + \\
\hline D1-BT & + & + & - & - & + & - & - & + & + \\
\hline K & + & - & + & + & - & - & - & + & + \\
\hline E1 & + & - & + & + & + & - & + & + & + \\
\hline S1 & + & - & + & + & + & - & + & + & + \\
\hline S2 & + & - & + & + & + & - & + & - & + \\
\hline P & + & - & + & + & + & - & + & + & + \\
\hline E2 & + & - & + & + & + & - & + & - & + \\
\hline
\end{tabular}

PT Pseudomonas, BT Bacillus, K Klebsiella, P Pneumonia, E1, E2 E. coli, S1, S2 Salmonella, P Proteus 


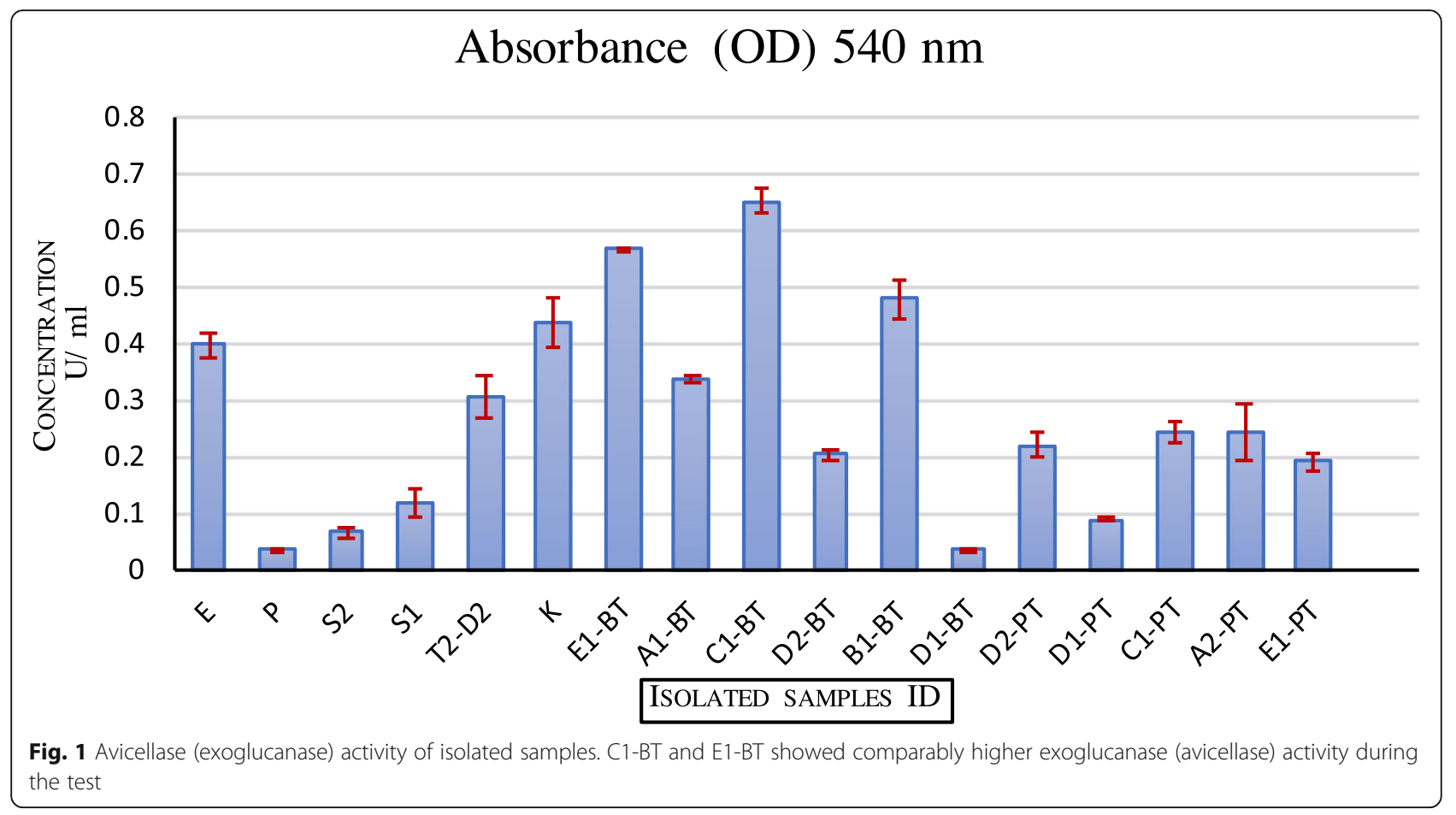

\section{Molecular identification}

From the 16S rRNA sequence data of E1-PT strain and T2-D2, the Bacillus sp. strain T2-D2 does not match with any particular Bacillus spp. of the dataset, and Pseudomonas aeruginosa strain E1-PT matched well with particular species. The majority of the homologous sequence WAS acquired from the NCBI databank according to their higher percentage similarity and $E$-value $(<0)$ after submitting the FASTA format of the query sequence to BLASTn. The sequence belonged to Bacillus spp. and Pseudomonas aeruginosa (Fig. 5).

\section{Discussion}

Seventeen cellulolytic bacterial isolates were isolated in soil excavated from the mangrove forest of Bangladesh. Attempted isolation of cellulolytic microorganisms from multiple locations of Sundarbans resulted in the isolation of powerful manufacturers of cellulase such as Trichoderma, Aspergillus, Pellicularia, Penicillium, Acremonium, and Humicola, and these microorganisms have, however, been discovered to be susceptible to heat (Fujimoto et al. 2011). Nevertheless, the isolates in our current study are mesophilic cultured at $30^{\circ} \mathrm{C}$. So, it could be a potential strain for different industries, such as biofuel, laundry, detergent, pulp, and paper industries.

Some previous studies identified 22 aerobic bacterial strains that could hydrolyze cellulose which belonged to 10 different genera: Burkholderia (36.36\%), Bacillus (13.65\%), Citrobacter (13.65\%), Arthrobacter (9.10\%), Enterobacter (4.54\%), Chryseobacterium (4.54\%), Pandoraea
(4.54\%), Paenibacillus (4.54\%), Dyella (4.54\%), and Pseudomonas (4.54\%) (Liang et al. 2014), and Escherichia coli isolated from the bovine rumen and showed that this strain produces extracellular cellulases with significant exoglucanase activity at pH 6.8 (Pang et al. 2017). Pseudomonas genus as host for the surface display of cellulases provided proof-of-concept for a fast and straightforward cellulose breakdown process at elevated temperature (Tozakidis et al. 2016).

The identification of present isolates was carried out using various biochemical tests and 16S rRNA sequencing. In this study, most of the bacterial species belong to the Enterobacteriaceae, Morganellaceae, Bacillaceae, and Pseudomonadaceae families. These bacterial species were either gram-positive or gram-negative, but their cellulase secreting capability was different according to their cellulose-decaying characteristics. Some of the strain fermented ethanol or liberated harmful gases, and some strain fermented lactose in the aerobic condition.

This study opens up new perspectives for applying Pseudomonas spp. in the production of biofuels and other biotechnological products. P. aeruginosa, P. fluorescens, $P$. mallei, $P$. putida, and $P$. syringae are mainly abundant in the soil. Moreover, we observed that salt concentration in mangrove soil is higher than regular soil. Therefore, it can also be deduced that these isolates are salt-tolerant than other bacterial species.

At the submerged fermentation process, our isolates (Bacillus spp. and Pseudomonas aeruginosa) produced a 


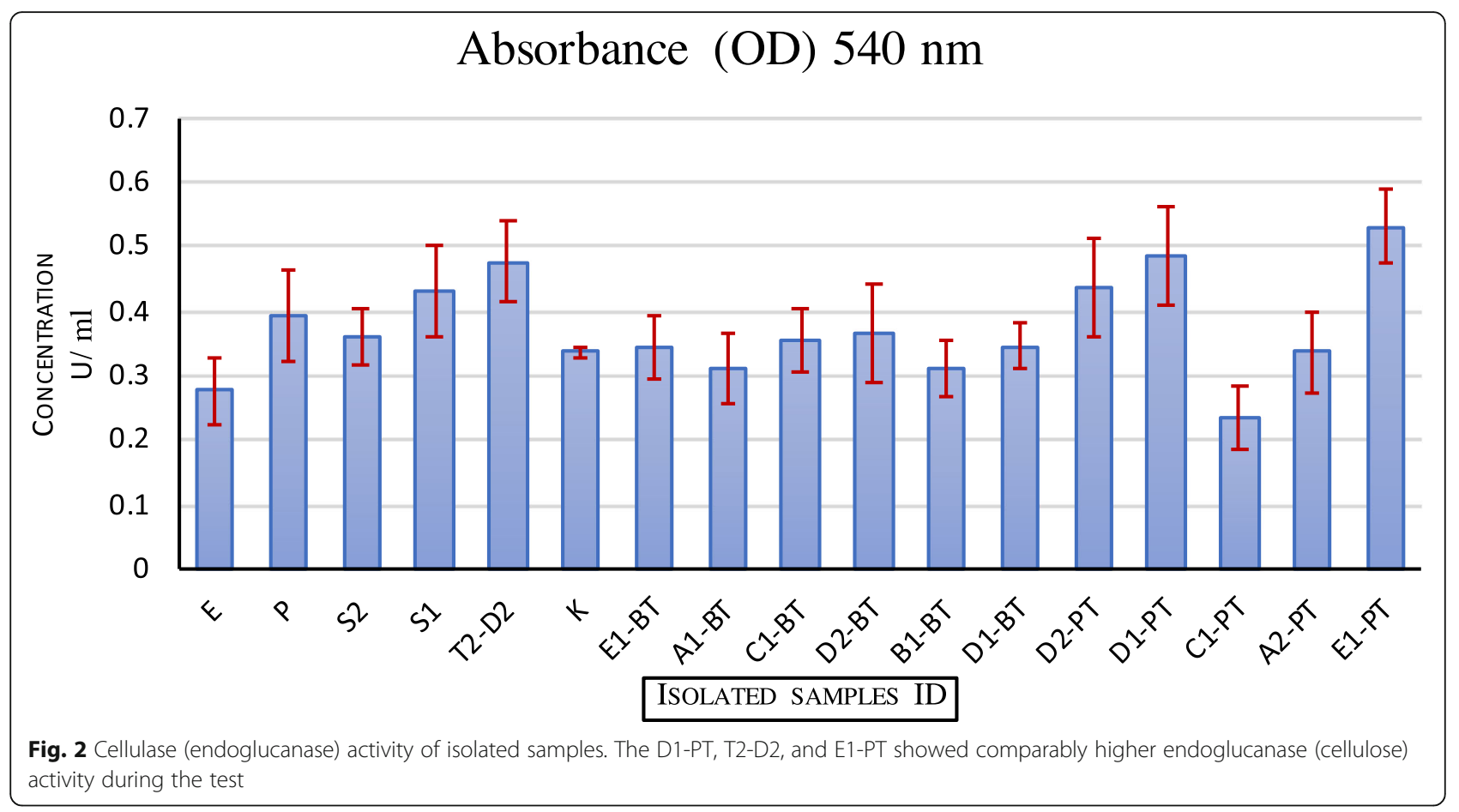

certain level of cellulases under mesophilic conditions. The typical high growth rate in Bacillus spp. and Pseudomonas aeruginosa and their ability to secrete extracellular proteins is a feature of the bacteria to be implemented in several industrial applications. Further development of these isolates can be carried out through genetic engineering and execution of metabolic engineering. The classification enables us to monitor the fermentation in compliance with the different demands for improved industrial efficiency. An additional study on the microorganisms' physiology, pretreatment of cellulosic biomass for an increased microbial attack, processes of economic cellulase production, development of several required metabolites, and the use of knowledge in protein engineering can then be carried out to improve the specific activity of the relevant enzymes, system sensitivity, and stability.

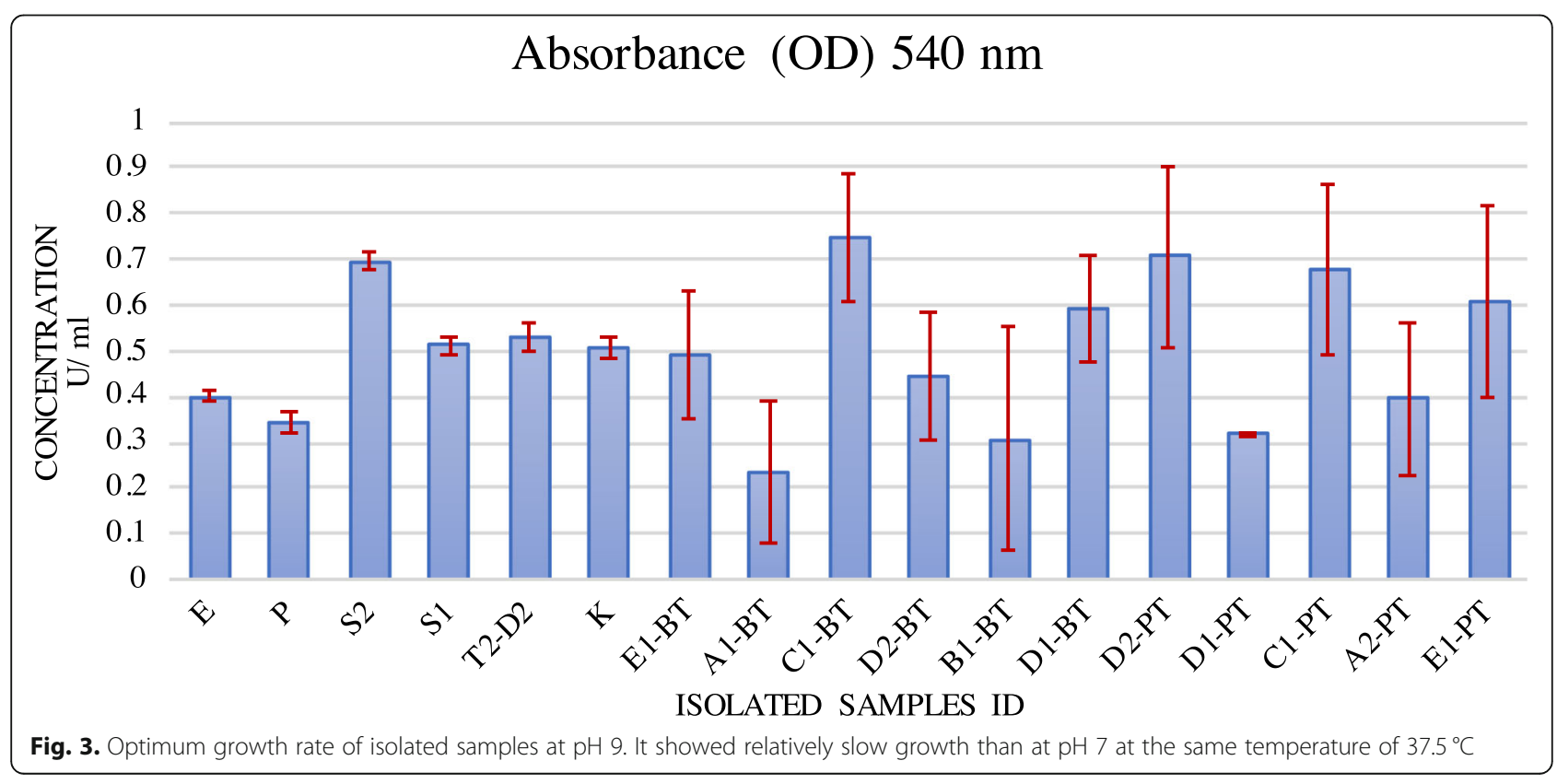




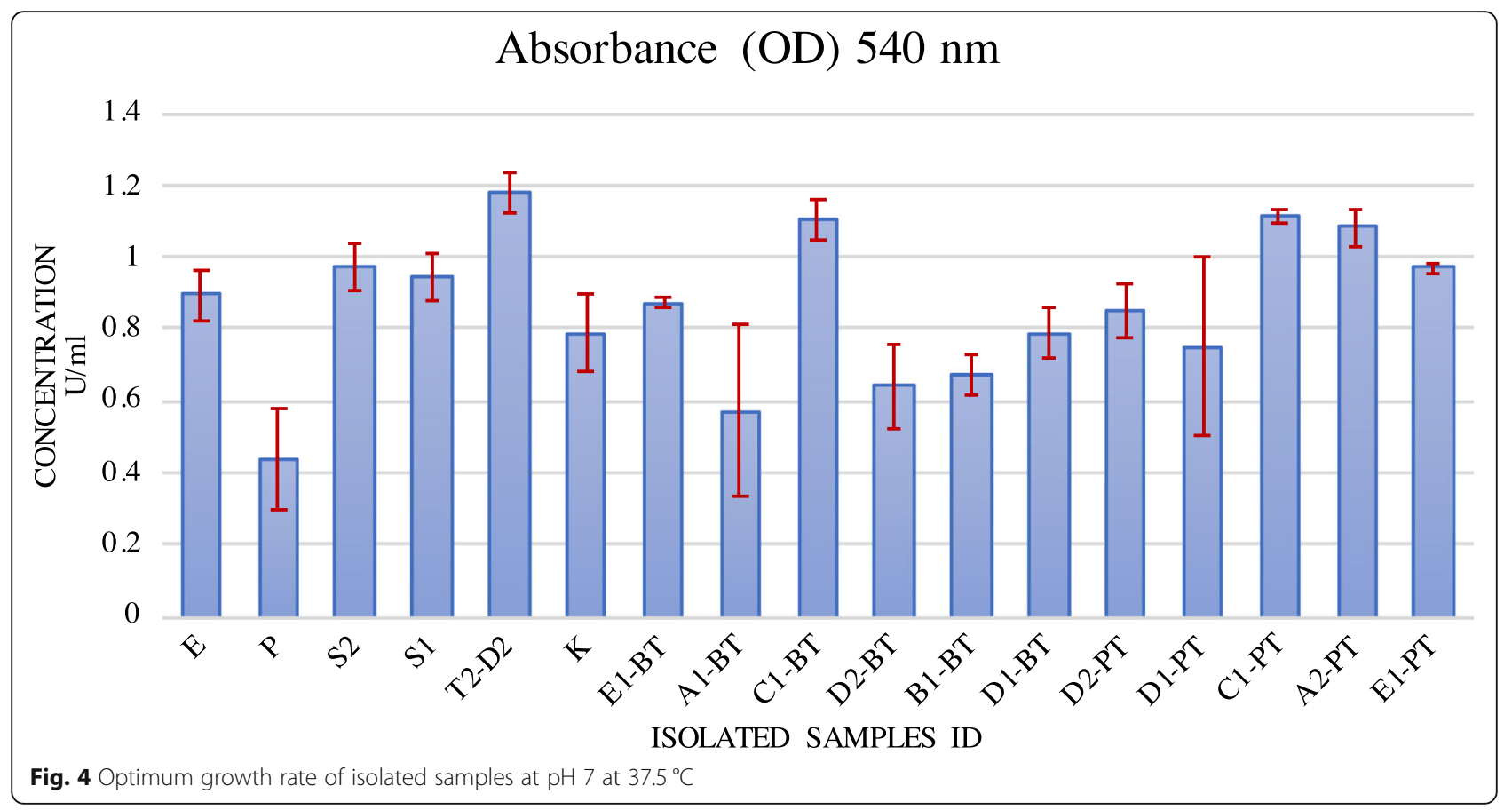

\section{Conclusions}

It can be concluded that four genera of bacteria hydrolyzing cellulose were isolated from the natural resources Sundarbans in Bangladesh. The strain E1-Pt, Pseudomonas spp., and T2-D2 strain of Bacillus spp. have shown supreme free cellulose-degrading efficiency (exoglucanases) among seventeen isolates. These genera hold pathways for the degradation of cellulose and related polymers because these bacteria can successfully form a colony at CMC agar media. By contrast, Bacillus spp. C1-Bt strain and T2-D2 strain showed the highest microcrystalline cellulose (Endoglucanases, cellulosomes) degrading efficiency by far.

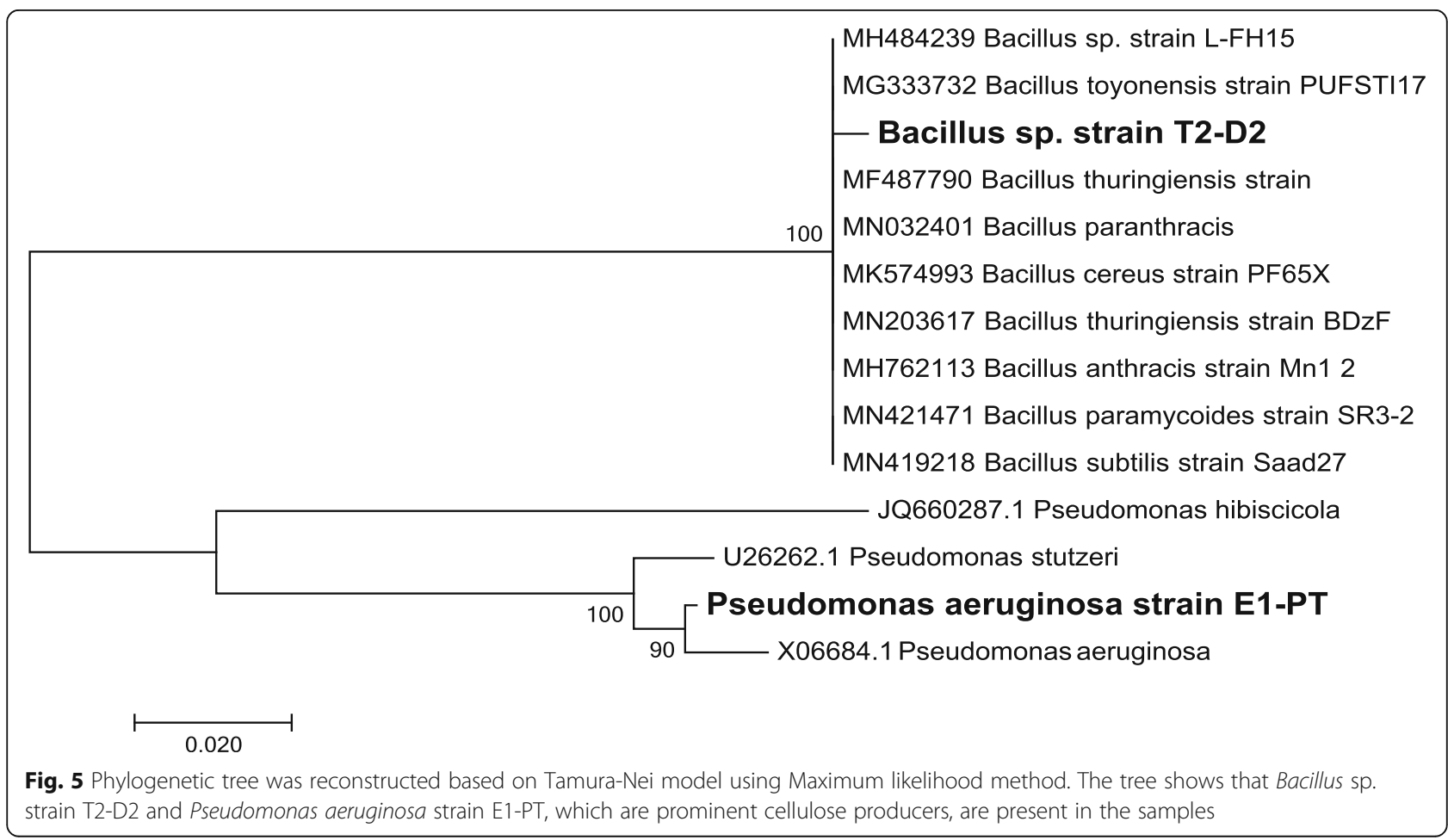


Moreover, it can be easily cultured at an average temperature $\left(37^{\circ} \mathrm{C}\right)$. On the one hand, T2-D2 (Bacillus spp.) and E1-PT (Pseudomonas spp.) have shown the highest growth rate at $\mathrm{pH} 7$ as it was neither acidic nor basic. The isolated strains were mesophilic because it was cultivated at $37^{\circ} \mathrm{C}$ compared to a previous study wherein the isolates were heat sensitive. However, we need to investigate further about these bacterial strains to trace out whether recombinant DNA technology could enhance their cellulolytic properties more for industrial purposes indeed.

\section{Acknowledgements}

The authors are grateful to the Centre for Sophisticated Instrumentation and Research Laboratory, Jashore University of Science and Technology for providing the laboratory facilities for our biochemical analysis.

\section{Authors' contributions}

SB and MAS are the principal investigators. IAT, MAK, MAI, MSH, ASMRUA, and MIKJ contributed partially, where MNH was the principal designer and responsible for this research. MSH helped to perform the phylogenetic analysis. All author(s) read and approved the final manuscript.

\section{Funding}

Our fund was used to conduct the research.

\section{Ethics approval and consent to participate}

This article does not contain any studies with human participants or animals performed by any of the authors. Informed consent was obtained from all individual participants included in the study.

\section{Competing interests}

The authors declare they have no competing interests.

\section{Author details}

${ }^{1}$ Laboratory of Pharmaceutical Biotechnology, Department of Genetic Engineering and Biotechnology, Faculty of Biological Science and Technology, Jashore University of Science and Technology, Jashore 7408, Bangladesh. ${ }^{2}$ Center for Bioinformatics, Universitat Des Saarlandes, Saarbrucken, Germany. ${ }^{3}$ Department of Microbiology, Faculty of Biological Science and Technology, Jashore University of Science and Technology, Jashore 7408, Bangladesh.

Received: 11 April 2020 Accepted: 4 November 2020

Published online: 07 December 2020

\section{References}

Anonymous (1981) General identification of bacteria. In: Kenya MO (ed) Manual of Veterinary Laboratory Techniques in Kenya. Ministry of Livestock Development Kenya, Nairobi, pp 1-24

Artzi L, Dassa B, Borovok I, Shamshoum M, Lamed R, Bayer EA (2014) Cellulosomics of the cellulolytic thermophile Clostridium clariflavum. Biotechnol Biofuels 7(1):100

Barkalow DG, Rowell RM, Young RA (1989) A new approach for the production of cellulose acetate: acetylation of mechanical pulp with subsequent isolation of cellulose acetate by differential solubility. J Appl Polym Sci 37(4):10091018

Barman D, Saud ZA, Habib MR, Islam MF, Hossain K, Yeasmin T (2011) Isolation of cellulytic bacterial strains from soil for effective and efficient bioconversion of solid waste. Life Sci Med Res 25:1-7

Bayer EA, Chanzy H, Lamed R, Shoham Y (1998) Cellulose, cellulases and cellulosomes. Curr Opin Struct Biol 8(5):548-557

Biswas SR, Choudhury JK, Nishat A, Rahman MM (2007) Do invasive plants threaten the Sundarbans mangrove forest of Bangladesh? For Ecol Manage 245(1-3):1-9

Boon EM, Downs A, Marcey D. "Proposed Mechanism of Catalase". Catalase: $\mathrm{H}_{2} \mathrm{O}_{2}$ : $\mathrm{H}_{2} \mathrm{O}_{2}$ Oxidoreductase Catalase Structural Tutorial. Retrieved 2007-02-11.
Buchanan RE, Gibbons NE (eds) (1974) Bergey's Manual of determinative Bacteriology, 8th edn. The Williams and Wilkins Co, Baltimore

Ekperigin MM (2007) Preliminary studies of cellulase production by Acinetobacter anitratus and Branhamella sp. Afr J Biotechnol 6(1):028-033

Eriksson KEL, Blanchette RA. and Ander P, 2012. Microbial and enzymatic degradation of wood and wood components. Springer Science \& Business Media. Springer-Verlag Berlin Heidelberg 89-180

Fujimoto N, Kosaka T, Nakao T, Yamada M (2011) Bacillus licheniformis bearing a high cellulose-degrading activity, which was isolated as a heat-resistant and micro-aerophilic microorganism from bovine rumen. Open Biotechnol J 5:7-13

Gupta P, Samant K, Sahu A (2012) Isolation of cellulose-degrading bacteria and determination of their cellulolytic potential. Int J Microbiol 2012 https://doi. org/10.1155/2012/578925

Henrissat B, Teeri TT, Warren RAJ (1998) A scheme for designating enzymes that hydrolyse the polysaccharides in the cell walls of plants. FEBS Lett 425(2): 352-354

Holguin G, Bashan Y (1996) Nitrogen-fixation by Azospirillum brasilense Cd is promoted when co-cultured with a mangrove rhizosphere bacterium (Staphylococcus sp.). Soil Biol Biochem 28(12):1651-1660

Holt JG, Krieg NR (1984) Bergey's manual of systematic bacteriology, vol 1. The Williams and Wilkins Co., Baltimore, pp 1-1388

Jackson ML (1956) Soil Chemical Analysis--Advanced Course: published by the author. Madison, Wisconsin, p 991

Khan AL, Shahzad R, Al-Harrasi A, Lee IJ (2017) Endophytic microbes: a resource for producing extracellular enzymes. In: Endophytes: Crop Productivity and Protection. Springer, Cham, pp 95-110

Lamed R, Naimark J, Morgenstern E, Bayer EA (1987) Specialized cell surface structures in cellulolytic bacteria. J Bacteriol 169(8):3792-3800

Liang YL, Zhang Z, Wu M, Wu Y, Feng JX (2014) Isolation, screening, and identification of cellulolytic bacteria from natural reserves in the subtropical region of China and optimization of cellulase production by Paenibacillus terrae ME27-1. Biomed Res Int 2014 https://doi.org/10.1155/2014/512497

Lynd LR, Weimer PJ, Van ZyI WH, Pretorius IS (2002) Microbial cellulose utilization: fundamentals and biotechnology. Microbiol Mol Biol Rev 66(3):506-577

MacFaddin JF (1985) Media for isolation-cultivation-identification-maintenance of medical bacteria, 7th edn. Williams \& Wilkins, Baltimore, p c1985 Agatha Ramm

Manfredi AP, Ballesterosb I, Sáezb F, Perottia NI, Martíneza MA, Negro MJ (2018) Integral process assessment of sugarcane agricultural crop residues conversion to ethanol. Bioresource Technology 260:241-247

McFadden BA (1980) A perspective of ribulose bisphosphate carboxylase/ oxygenase, the key catalyst in photosynthesis and photorespiration. Acc Chem Res 13(11):394-399

Millar BC, Jiru XU, Moore JE, Earle JA (2000) A simple and sensitive method to extract bacterial, yeast and fungal DNA from blood culture material. $J$ Microbiol Methods 42(2):139-147

Pang J, Liu ZY, Hao M, Zhang YF, Qi QS (2017) An isolated cellulolytic Escherichia coli from bovine rumen produces ethanol and hydrogen from corn straw. Biotechnol Biofuels 10(1):165

Shaikh NM, Patel AA, Mehta SA, Patel ND (2013) Isolation and screening of a cellulolytic bacteria inhabiting different environment and optimization of cellulase production. Univ J Environ Res Technol 3(1):39-49

Sigma-Aldrich Co. (n.d.). Retrieved from https://www.sigmaaldrich.com/catalog/ product/sial/85463?lang $=$ ja ${ }^{\oplus i o n}=J P$

Singh S, Jaiswal DK, Sivakumar N, Verma JP (2019) Developing Efficient Thermophilic Cellulose Degrading Consortium for Glucose Production from Different Agro-Residues. Frontiers in Energy Research 7:61

Swenson J, Patel J, Jorgensen J (2011) Phenotypic Methods for Detecting Antibacterial Resistance. In: Versalovic J, Carroll K, Funke G, Jorgensen J, Landry M, Warnock D (eds) Manual of Clinical Microbiology, 10th edn. ASM Press, Washington, DC, pp 1155-1179

Teeri TT (1997) Crystalline cellulose degradation: new insight into the function of cellobiohydrolases. Trends Biotechnol 15(5):160-167

Thatoi H, Behera BC, Mishra RR (2013) Ecological role and biotechnological potential of mangrove fungi: a review. Mycology 4(1):54-71

Tille P (2016) Bailey \& Scott's Diagnostic Microbiology, 14th Edition,. Mosby. In: 289 pp Chap-19

Tittler RP, Sandholzer LAJ (1996) J Bacteriol 31:575

Tomme P, Warren RAJ, Gilkes NR (1995) Cellulose hydrolysis by bacteria and fungi. In: Advances in microbial physiology, vol 37. Academic Press, pp 1-81 
https://sci-hub.se/https:/www.sciencedirect.com/science/article/abs/pii/ S0065291108601435

Tozakidis IE, Brossette T, Lenz F, Maas RM, Jose J (2016) Proof of concept for the simplified breakdown of cellulose by combining Pseudomonas putida strains with surface displayed thermophilic endocellulase, exocellulase and $\beta$ glucosidase. Microb Cell Fact 15(1):103

\section{Publisher's Note}

Springer Nature remains neutral with regard to jurisdictional claims in published maps and institutional affiliations.

Ready to submit your research? Choose BMC and benefit from:

- fast, convenient online submission

- thorough peer review by experienced researchers in your field

- rapid publication on acceptance

- support for research data, including large and complex data types

- gold Open Access which fosters wider collaboration and increased citations

- maximum visibility for your research: over $100 \mathrm{M}$ website views per year

At $\mathrm{BMC}$, research is always in progress.

Learn more biomedcentral.com/submissions 